\title{
29. A SUMMARY OF ODP LEG 141 HYDROGEOLOGIC, GEOCHEMICAL, AND THERMAL RESULTS 1
}

\author{
K.M. Brown, ${ }^{2}$ N. Bangs,${ }^{3}$ K. Marsaglia, ${ }^{4}$ P.N. Froelich,${ }^{5}$ Y. Zheng, ${ }^{5}$ B. M. Didyk, ${ }^{6}$ D. Prior, ${ }^{7}$ E.L. Rochford, ${ }^{7}$ \\ M. Torres, ${ }^{8}$ V.B. Kurnosov, ${ }^{9}$ N. Lindsley-Griffin,${ }^{10}$ S. Osozawa, ${ }^{11}$ and A. Waseda ${ }^{12}$
}

\begin{abstract}
The subduction of the oceanic spreading center at the Chile Triple Junction is marked by a substantial thermal perturbation and marked changes in the hydrogeologic and aqueous geochemical regimes in the overthrust plate. Ridge subduction substantially changes the fluid chemistry in the wedge through variably hydrating the oceanic basement, accretionary wedge, and continental backstop. This generates positive anomalies in salinity and chloride values with respect to sea water. The wedge immediately above the subducted ridge also experiences greatly enhance diagenesis and cementation together with the influx of primordial mantle derived ${ }^{4} \mathrm{He}$.

Linear temperature and pore fluid chemistry profiles suggest a predominantly diffusive/conductive regime predominates in the interior eastern portion of the wedge and continental backstop region. In contrast, a vigorous and transient hydrogeolgic system within $5 \mathrm{~km}$ of the toe of the wedge at both Sites 859 and 863 generates spatially narrow, large, and complex anomalies in temperature and fluid chemistry. At the toe the vigorous hydrogeologic system may be variably influenced by the episodic expulsion of fluid from both the deeper parts of the wedge and oceanic basement driven convection systems. Structural and diagenetic observations are also consistent with a hydrogeologic regime that both evolves with time and that is dominated by episodic processes. In particular, studies of cements, mineralized veins, deformation bands, and Fe sulfide distribution suggest that above the subducting ridge (i.e., Site 863) the lithification in the wedge is greatly enhanced and that and periods of enhanced fluid expulsion are associated with local hydrofracture and dilation episodes.
\end{abstract}

\section{INTRODUCTION}

The Chile Triple Junction (CTJ; Figs. 1 and 2) is one of only two world-wide examples where an oceanic/transform spreading axis is currently being subducted beneath continental lithosphere. Ridge subduction has, however, occurred along many Pacific subduction zones in the past and the study of this currently active system can be used to constrain onshore investigations of the effects of these paleoridge subduction events. Spreading ridge subduction should leave a distinctive mark on the structural and hydrogeologic processes in the overriding subducting crust, mantle, and where present, accretionary wedge (see for example references in Underwood, 1993). On land studies in convergent margin systems that have experienced past ridge subduction events, for example, portions of the Franciscan along California coast and the Shimanto belt of Japan, strongly suggest that ridge subduction is associated with an increase in the thermal

'Lewis, S.D., Behrmann, J.H., Musgrave, R.J., and Cande, S.C. (Eds.), 1995. Proc. ODP. Sci. Results, 141: College Station, TX (Ocean Drilling Program).

Scripps Institution of Oceanography, University of California, La Jolla, CA 92093. 0220, U.S.A. U.S.A.

Institute of Geophysics, University of Texas at Austin, Austin, TX 78759-8397.

${ }^{4}$ Department of Geological Sciences, University of 'Texas at El Paso, EI Paso, TX 79968-0555, U.S.A. U.S.A.

${ }^{5}$ Lamont-Doherty Earth Observatory, Columbia University, Palisades, NY 10964.

${ }^{6}$ Research and Development Laboratory, Empresa Nacional del Petróleo, Refinería de Petróleos de Concón, S.A., Casilla 242, Concón, Chile.

7 Department of Earth Sciences, University of Liverpool, Liverpool L69 3BX, United Kingdom.

${ }^{8}$ GEOMAR, Wischhofstrasse 1-3, Gebăude 12, D-2300 Kiel 14, Federal Republic of Germany.

${ }^{9}$ Geological Institute, Academy of Sciences, Pyzhevsky per., 7. Moscow 109017. Russia.

${ }^{10}$ Department of Geology, University of Nebraska, 214 Bessey Hall, Lincoln, NE 68588-0340, U.S.A.

"Institute of Geology and Paleontology, Faculty of Science, Tohoku University, Aoba, Sendai 980, Japan.

12 JAPEX Research Center, 1-2-1 Hamada, Mihama-ku, Chiba 261, Japan. maturation or metamorphic grade in the overthrust upper plate materials (Cloos, 1993; DeLong et al., 1979; Underwood, 1993). The enhanced thermal and fluid-rock interactions in the Franciscan in the Big Sur Region and the King Range in California (Underwood et al., 1989; Underwood et al., 1990) are also examples of the potential manifestations of past ridge subduction events.

The Chile Triple Junction was investigated during ODP Leg 141 partly to constrain the thermal, geochemical, and hydrogeologic processes occurring during active ridge subduction (Behrmann et al., this volume). The resulting data reveal a highly heterogeneous pattern of processes that are transient on a variety of time scales. In particular, it appears that the peak in thermal regime should be closely associated with a relatively short lived collisional system dominated by elevated salinities, thermal gradients, and oceanic hydrothermal influences.

\section{Heat Flow Patterns}

South of the Darwin Fracture Zone (DFZ) (Fig. 1), significant accretion and tectonic thickening has not occurred since Pleistocene times (Behrmann et al., this volume). Here it is suggested that sediments on the subducted plate bypass the toe and become thrust deep beneath the wedge. Indeed, substantial subduction erosion is probably occurring in this region (Behrmann et al., this volume; Cande et al., 1987). The spreading axis is 0 to $1 \mathrm{~m}$.y. from being subducted and very high heat flows (greatly in excess of $250 \mathrm{mWm}^{-2}$ ) were expected from this practically zero age crust. The transact of holes (Sites 859 to 861 ) along Line 745 (Figs. 1 and 2) characterizes the changing nature of the regional thermal regime across the accretionary wedge just prior to ridge subduction (Fig. 3). Temperature gradients are moderate $\left(50^{\circ}-60^{\circ} \mathrm{C} / \mathrm{km}\right)$ and dominantly linear in the older eastern regions of the wedge (i.e., Site 861 , Figs. 2 and 3), while high temperature gradients $\left(>80^{\circ}-100^{\circ} \mathrm{C} / \mathrm{km}\right)$ and highly non-linear down hole profiles are found near the toe of the wedge (i.e., Sites 859 and 863 , Figs. 2 and 3). When both temperature measurements from the shallow (0-50 mbsf) portions of the ODP holes and surface probe data are combined to form a profile across the wedge it can be seen that the shallow heat flow increases in highly nonlinear fashion toward the 


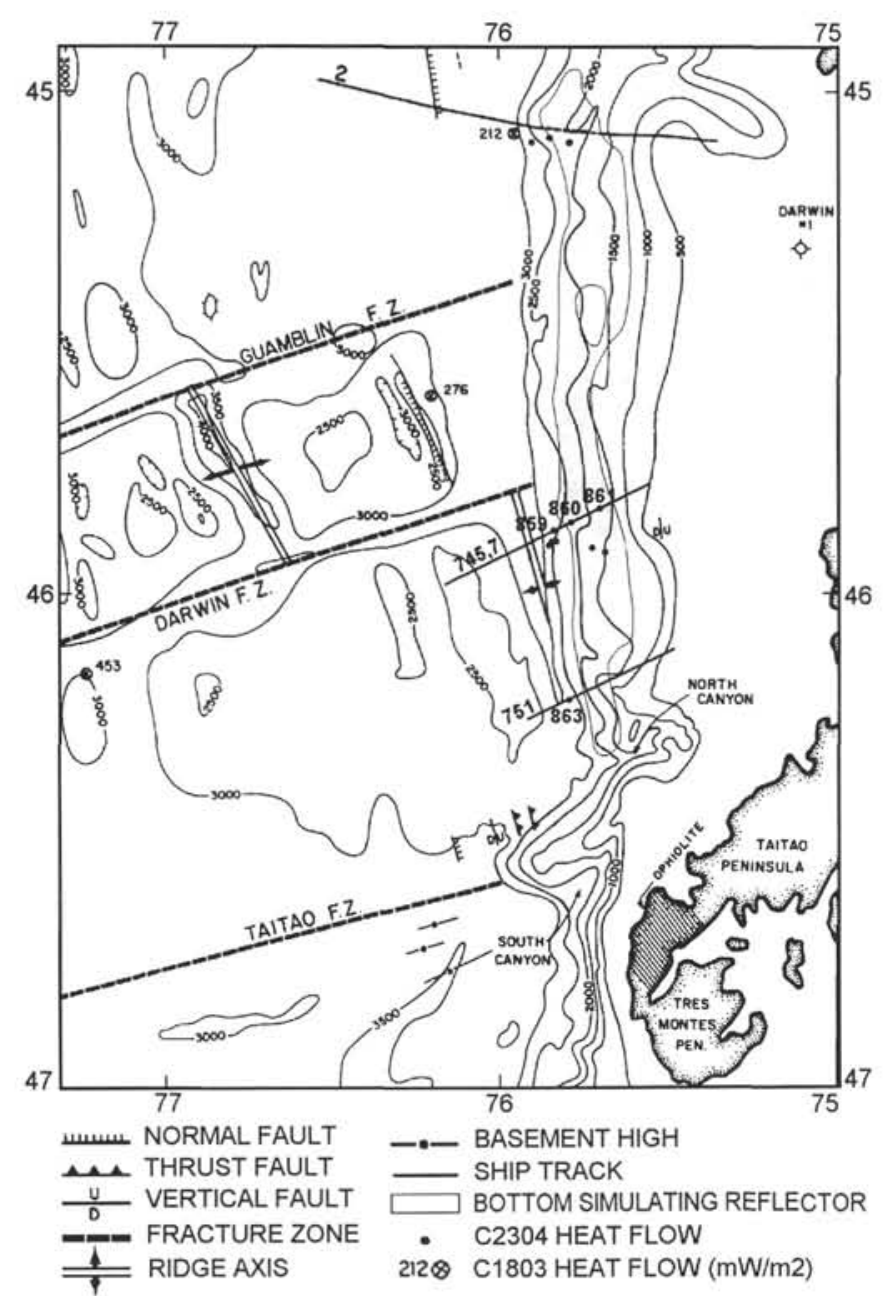

Figure 1. Location maps showing the general tectonic elements in the Chile Triple Junction Region and gas hydrate distribution.

accretionary toe and then drops sharply just seaward of the wedge (see Brown and Bangs, this volume).

Another significant feature is the large offset between heat flow estimates (Brown and Bangs, this volume) based on shallow ( $<50$ mbsf) and deep temperature measurements (at depths $>50 \mathrm{mbsf}$ ) within $5 \mathrm{~km}$ of the deformation front (Fig. 4). Near the deformation front, the shallow temperature measurements in the wedge record a consistently and substantially higher geothermal gradient and corresponding heat flow (with a maximum difference of a little under 200 $\mathrm{mWm}{ }^{-2}$ between the shallow and deep heat flow values) than is either determined for bore hole measurements for regions below $50 \mathrm{mbsf}$ or estimates based on the depth of the BSR as seen on seismic reflection sections (Bangs and Brown, this volume; Brown and Bangs, this volume). This offset is proposed to relate to convex temperature profiles (Brown and Bangs, this volume), generated by considerable amounts of upward warm fluid advection, becoming predominant near the toe of the wedge (Fig. 4). The non-linear temperature profiles at Sites 859 and 863 (Fig. 3) provide direct evidence for the complexity in the nature of this fluid flow. The temperature profile at Site 859, for example, has a convex curvature at shallow depths and highly complex morphology at depth.

\section{GEOCHEMICAL CONSTRAINTS ON THE ORIGIN OF FLUIDS IN THE ACCRETIONARY PRISM}

The pore-fluid geochemistry indicates that the Chile Triple Junction region differs from other previously studied accretionary prisms in terms of its internal fluid source characteristics. Salinity and chloride values vary strongly across the wedge with both positive and negative anomalies (with respect to sea water values) occurring in different tectonic environments. Figure 5 summarizes the chlorinity and total cation charge with depth for each of the sites in the accretionary wedge (locations shown on Figs. 1 and 2).

The data (Fig. 5) indicate that pore fluid salinities and chloride values are generally elevated both near the toe of the wedge (Sites 859 and 863) and in the most arcward regions of the wedge (861). In contrast, slightly reduced salinities and chloride values are observed in the central portion of the wedge (Site 860). Chloride is a conservative constituent that is not normally directly involved in mineral reactions; therefore, trends in aqueous chloride concentration are commonly used to identify patterns of water expulsion (resulting in negative chloride anomalies) and uptake (resulting in positive chloride anomalies) respectively during mineral dehydration and hydration reactions (i.e., Gieskes et al., 1990a, b; Kastner et al., 1991; Vrolijk et al., 1991).

At Site 859 the fluid chemistry at the toe of the prism (Site 859 . Figs. 2, 5 and 6) is dominated by the low/moderate temperature diagenetic alteration of oceanic basement components to clay minerals. Evidence for this is based on the increase in salinity and $\mathrm{Ca}$, decrease in $\mathrm{Mg}$ and $\mathrm{Na}$, the depletion of $\delta^{18} \mathrm{O}$ with respect to sea water in the pore fluids with depth (Behrmann et al., 1992; Torres et al., this volume; Zheng et al., this volume), and a downhole decrease in volcaniclastic components (Marsaglia et al., this volume). Chloride values, for example, are also increased by up to $\sim 10 \%$ at this site (Fig. 5 ).

There are large thermal (Fig. 3) and chemical (Fig. 6) disturbances and poor correlation between $\mathrm{Ca}, \mathrm{Mg}$, and $\delta^{18} \mathrm{O}$ in the geochemical profiles, particularly evident around $\sim 245 \mathrm{mbsf}$ at Site 859 . There is also a positive spike in the $\delta^{13} \mathrm{C}$ (methane) values at the level of the thermal anomaly suggesting that it is also the site of thermogenic hydrocarbon migration from a hotter $\left(>80^{\circ} \mathrm{C}\right)$ source at depth (Waseda and Didyk, this volume). These anomalies suggest that the upward diffusive chemical gradients are locally disrupted by lateral fluid flow at this level. The organic chemistry and $\delta^{13} \mathrm{C}$ values indicate low degrees of organic thermal maturity at Site 859 and, apart from the thermogenic methane anomaly at $\sim 245$ mbsf, most of the methane/ethane gas component appears to be bacterial in origin (Kvenvolden et al., this volume; Waseda and Didyk, this volume). These data are inconsistent with high temperatures, such as those at $\sim 245$ mbsf at Site 859 (Fig. 3), having been maintained for any great length of time.

Site 860 , situated in a mid-slope basin (Fig. 2 ), has the least saline fluids and lowest chlorinity values of any of the sites drilled across the wedge. There are anomalies in the pore fluid chemistry profiles centered at $\sim 200 \mathrm{mbsf} \pm 20 \mathrm{~m}$ and $360 \mathrm{mbsf} \pm 20 \mathrm{~m}$ (Figs. 5 and 7). The 200 and $360 \mathrm{mbsf}$ levels are associated with negative anomalies in chloride and ionic strengths (Fig. 5) with, for example, chloride values falling $\sim 15 \%$ below seawater values at $360 \mathrm{mbsf}$. It is possible that the freshened zone at $200 \mathrm{mbsf}$ relates to the dissociation of gas hydrates after core recovery because a bottom simulating reflector is identifiable at about this level in seismic reflection section (Bangs et al., this volume). The deeper negative chloride anomaly at $\sim 360 \mathrm{mbsf}$, however, appears to more clearly reflect the lateral input of freshened fluids derived from either clay dehydration reactions (which occur predominately between $\sim 100^{\circ}-120^{\circ} \mathrm{C}$ ) or membrane filtration effects (Gieskes et al., 1990a, b). A thermogenic methane gas component was also identified in the deeper regions of Site 860 (Waseda and Didyk, this volume). Mixing line calculations between bacterial and thermogenic end members suggest that there has been an addition of $\sim 5 \%$ thermogenic component (Waseda and Didyk, this volume). The low thermal maturity of the organic matter at Site 860 , however, indicates these thermogenic components could not have been generated in situ and must have migrated into the section from depth. While there is no $\delta^{13} \mathrm{C}$ (ethane) data above $320 \mathrm{mbsf}$, there is a strong gradient in $\delta^{13} \mathrm{C}$ (ethane) across the interval around $360 \mathrm{mbsf}$ that suggest the thermo- 

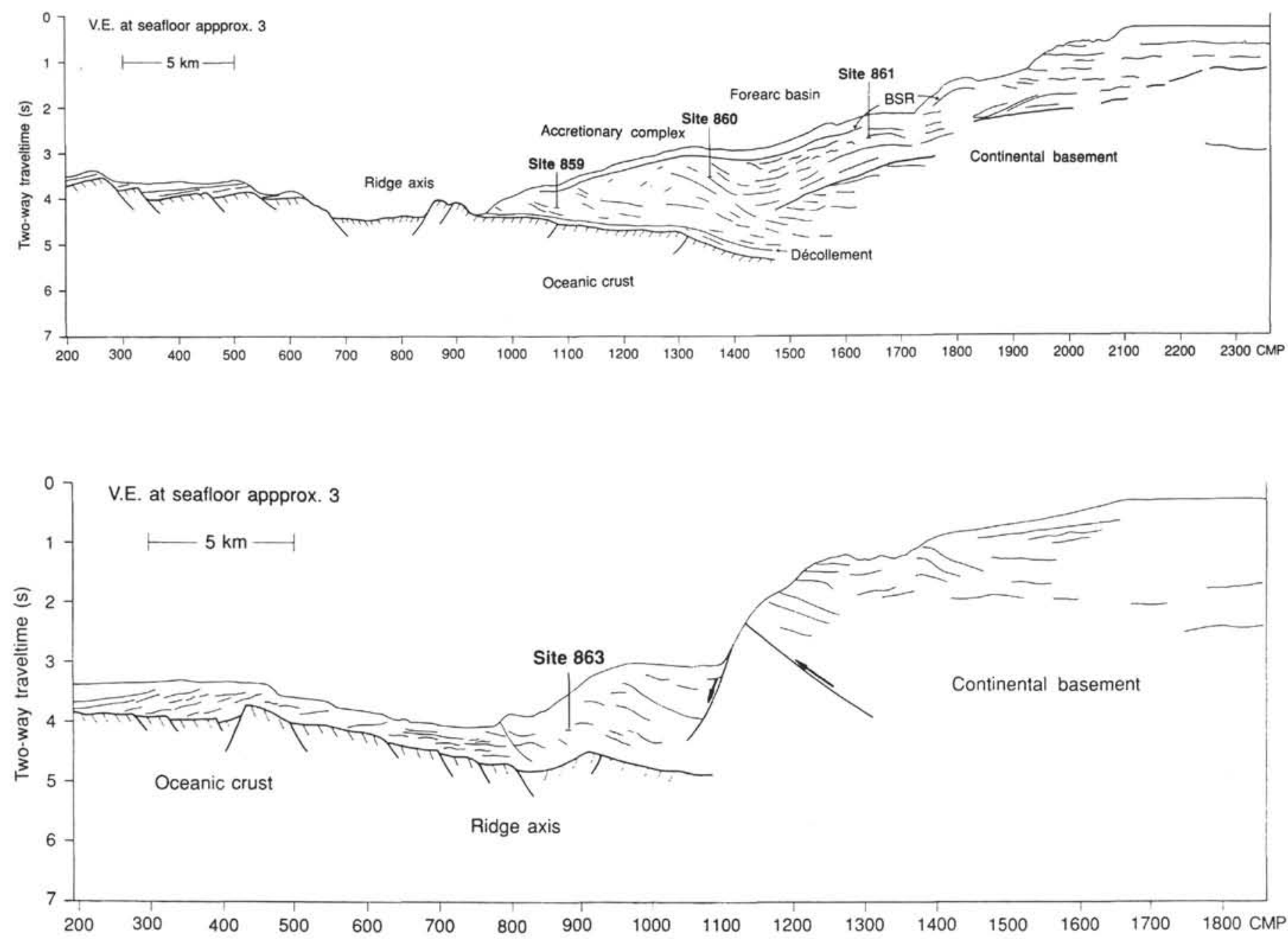

Figure 2. Line drawings of Lines 745 (above) and 751 (below) with ODP Leg 141 site locations (line locations shown on Fig. 1).

genic component is significantly enhanced below this potential lateral fluid conduit level.

At Site 861 the linear decrease in $\delta^{18} \mathrm{O}, \mathrm{K}$ and $\mathrm{Mg}$ and pronounced $20 \%$ down hole increase in chlorinity (above seawater values), and further increases in $\mathrm{Na}, \mathrm{Ca}$, and general ionic concentration with depth (Figs. 5 and 8 ) in the mid to upper slope region is consistent with the uptake of water during the alteration of volcanic and possibly continental basement materials (i.e., alkaline sericitization of plagioclase feldspar) to clay minerals. This observation is also consistent with this site's position above probable continental basement, based on its high seismic velocity (Behrmann et al., this volume). The aqueous geochemical profiles are generally linear at this site and, together with the linear temperature profiles, this suggests that there has been little significant lateral or vertical fluid flow at this site. The $\delta^{13} \mathrm{C}$ values at this site also indicate that the methane/ethane gas component is bacterially derived with little evidence for a deeply derived thermogenic component (Waseda and Didyk, this volume).

Site 863 lies in the wedge above the CTJ and the subducted oceanic spreading center (Figs. 1,2, and 9). This is the only site where primordial mantle derived heavy ${ }^{4} \mathrm{He}$ gases were identified as a dissolved component of the pore fluids (Torres et al., this volume). The ${ }^{4} \mathrm{He}$ is prominent in the interval between $\sim 60$ and $\sim 140 \mathrm{mbsf}$ and there is a ${ }^{4} \mathrm{He}$ peak at $\sim 80 \mathrm{mbsf}$. This anomalous zone of primordial ${ }^{4} \mathrm{He}$ is also associated with strong geochemical anomalies in $\mathrm{Mg}, \mathrm{Ca}, \mathrm{Sr}$, and $\mathrm{K}$ (Fig. 9) and a warm and relatively narrow temperature anomaly that suggests lateral flow of warm fluids are occurring along a fluid conduit close to $70 \mathrm{mbsf} \pm 10 \mathrm{~m}$ (Fig. 3). This interval is also the lower boundary of a zone enriched in Fe sulfides that is associated with both fracture controlled and diffusive fluid flow. A unique $\delta^{18} \mathrm{O}$ profile is observed at this site (Fig. 9), with increasing $\delta^{18} \mathrm{O}$ enrichment with depth. The associated chloride enrichment and generally increasing salinities with depth (Fig. 5) suggests this profile is generated by high-temperature basalt-water interaction involving the formation of hydrated greenschist minerals (e.g., chlorite) in hydrothermal systems in the oceanic basement (Torres et al., this volume; Zheng et al., this volume). Centered close to $450 \mathrm{mbsf} \pm 20 \mathrm{~m}$ is a zone of generally strongly reduced salinities associated with large discordances in the B, F, Li, Sr, Ca, Mg, K, Si profiles (Figs. 5 and 9). There is, however, no accompanying negative anomaly in the more chemically conservative chloride component (Fig. 5). Indeed, the chloride concentrations increase across this interval. This "freshened zone" is proposed to be a very diagenetically active area with ongoing cementation having removed some active ionic species but not the more conservative chloride component.

\section{EVIDENCE FOR THE EVOLVING NATURE OF THE COUPLING BETWEEN STRUCTURE, DIAGENESIS, AND FLUID FLOW}

\section{Deformation Bands}

Deformation bands are spatially correlatable with the intensity of deformation and the development of broken formation at Sites 860 and 863 (see "Site 860" and "Site 863" chapters in Behrmann, Lewis, and 

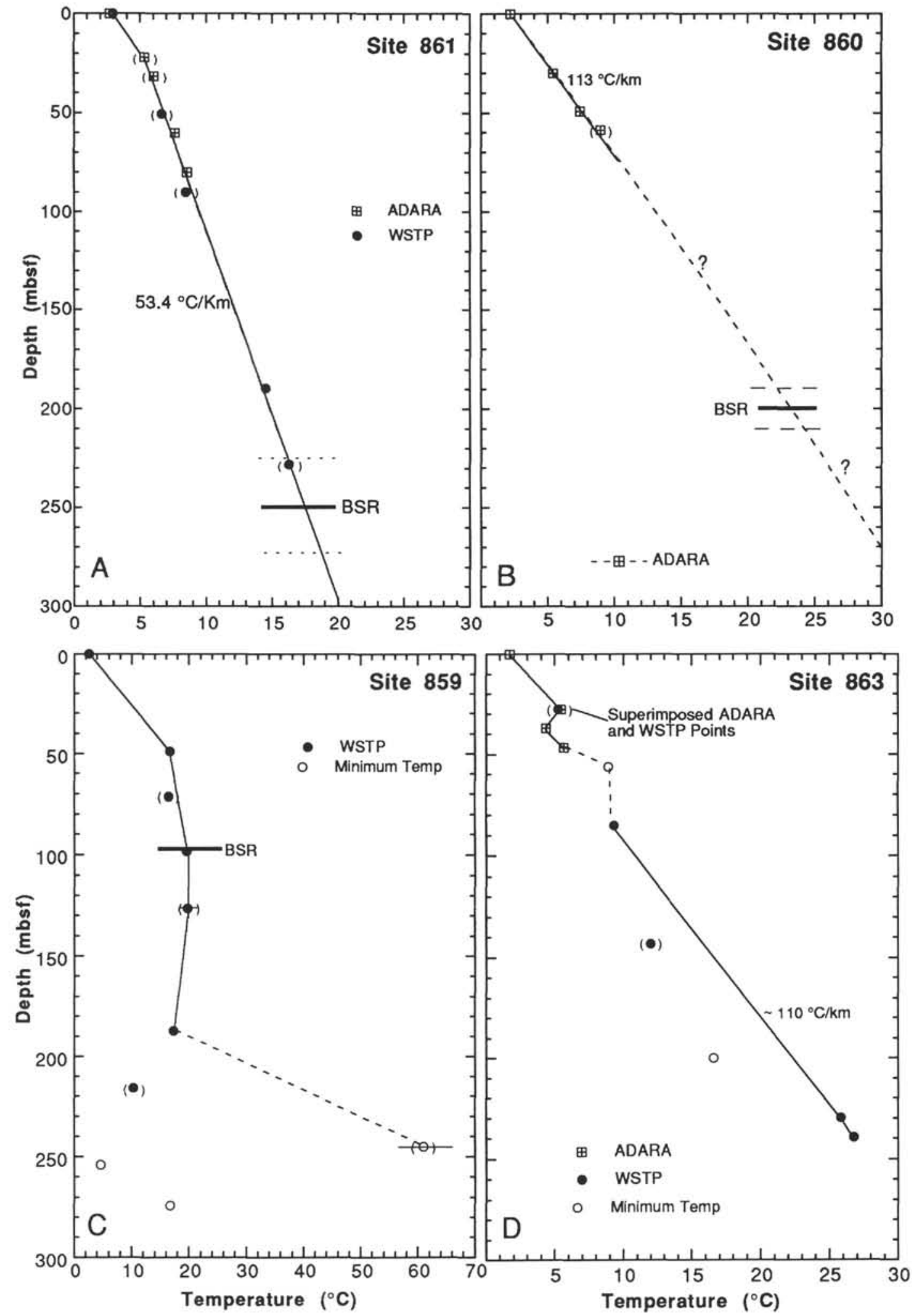

Figure 3. Downhole temperature profiles obtained during ODP Leg 141 (Brown and Bangs, this volume). Note the nonlinear nature of the temperature profiles at the toe of the wedge. 
Musgrave et al., 1992). As their name suggests, deformation bands are commonly associated with shear displacements. It has also been suggested, however, that they are the locus of fluid flow during transient periods of dilation (Agar and Prior, this volume; Prior et al., this volume; Rochford et al., this volume). The term deformation bands may refer to core scale features that have been generated by one or more processes. The main features of the deformation bands are: (a) Displacements are commonly seen across them. (b) They are variably associated with increased volumetric strain related to greater consolidation (Rochford et al., this volume). (c) Back scattered electron (BSE) images indicate that some bands have an increased fine grained clay matrix component that is linked to higher bulk densities and lower por- osities (Agar and Prior, this volume; Rochford et al., this volume). In some cases, there is a net increase in the clay proportion within the deformation band and cementation by clay minerals may be a significant factor in their development. (d) There is commonly a higher den- sity of iron sulfides within the deformation bands that may also contribute to their increased brightness in BSE images. (e) The grain sizes are often smaller in the deformation bands but there is little evidence of grain breakage. (f) In some cases foreign components not found in the walls of the deformation band appear to have been emplaced or injected along deformation bands. (g) Grain alignment parallel to the margins of the deformation band are occasionally prominent.

Apart form the obvious displacements across some deformation bands, detailed microstructural observations are consistent with the additional variable influences of several processes that are related to the flow of fluids through these features (Agar and Prior, this volume; Prior et al., this volume; Rochford et al., this volume). These processes may occur irrespective of shear displacements across the deformation bands. Some fabrics are consistent with aqueous fluid flow (with no solid particle movement) having been directed through dilated deformation bands; followed by subsequent collapse of the fracture generating aligned fabrics along the closure seam (Knipe et al., 1991). A second type relates to sediment injection, where the pore water and solid framework move together along fractures as an overpressured slurry. In this instance, the material filling the fractures can bear little resemblance to the wall sediments. Between these two end members are fluidized sediment intrusions where the water and sediment move separately with the rate of water movement sufficient to dynamically entrain the solid framework (Brown, 1990; Knipe et al., 1991). The third type involves the direct precipitation of authigenic phases (e.g., clays, Fe sulfides, calcite, or alteration of existing phases). Clear examples of this end member include the sulfide and calcite veins; in these instances material is carried in solution. It is quite possible, however, that more than one of these mechanisms is involved in formation of the deformation bands.

Framboidal iron sulfide is also widely distributed through the sediments at all sites. Magnetic studies indicate that Greigite forms as a significant proportion of the Fe sulfides seen in the Chile Triple Junction region (Musgrave et al., this volume). Greigite is an intermediate phase in the production of pyrite. Evidence that some sulfide deposition at Site 863 is associated with focused fluid flow is evident in fine grained sediments at a few centimeters below the seafloor in the form of discontinuous sulfide stringers and veins (Behrmann, Lewis, Musgrave, et al., 1992; Lindsley-Griffin et al., this volume). Iron sulfide deposition continues at depth where at Sites 860 and 863 , for example, it increasingly becomes spatially associated with deformation bands and faulting (Lindsley-Griffin et al., this volume; Rochford et al., this volume).

\section{Site 863: Evolving Patterns of Diagenesis and Fluid Flow}

Site 863 lies directly above the CTJ and is unique in terms of its tectonic, hydrogeologic and diagenetic history (Figs. 1 and 2). Visible evidence for the association of structural and hydrogeologic processes is first observed at shallow levels at this site in the form of the

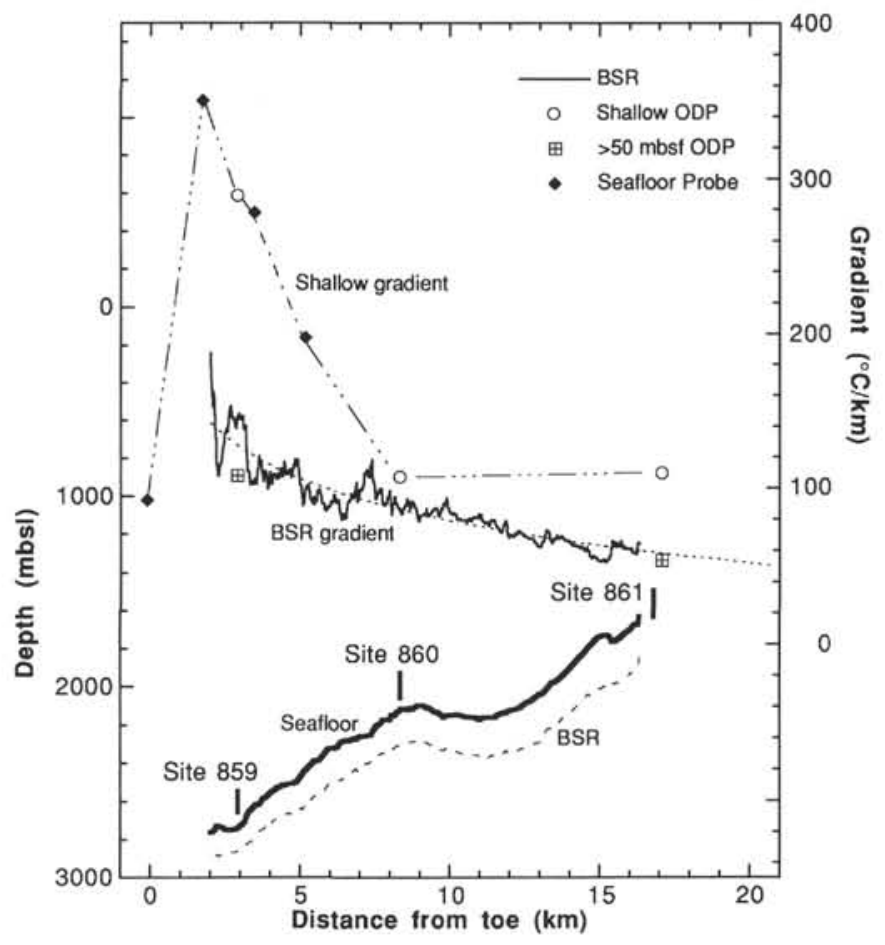

Figure 4. Figure showing the increasing discordance within $\sim 5 \mathrm{~km}$ resulting of the difference between shallow and deep ( $>50 \mathrm{mbsf}$ and BSR based) heat flow estimates due to enhanced fluid advection at the toe of the wedge (Brown and Bangs, this volume).

black sulfide rich mineralized fractures most prominent in a complexly deformed region between 3.3 and 42 mbsf (see Site 859 site Chapter in Behrmann, Lewis, Musgrave, et al., 1992). This sulfide rich region is also spatially associated with warm temperature anomalies $\left(\sim 3^{\circ} \mathrm{C}\right.$ warmer than ambient) located at $30 \mathrm{mbsf} \pm 10 \mathrm{~m}$ and perhaps at $70 \mathrm{mbsf} \pm 10 \mathrm{~m}$ (Fig. 3 ). These warm temperature anomalies are relatively narrow and appear to have been generated by a relatively recent influx of fluids, possibly along fractures similar to those now infilled by black sulfides.

Deeper in the section at Site 863 there is evidence for a complex cementation zone that has developed in sediments of late Pleistocene age. Limited cementation begins to be observed in the subvertically bedded sediments below $\sim 250$ mbsf (Fig. 10). Core scale and thin section observations indicate that carbonate cements sporadically occur below $200 \mathrm{mbsf}$, with clay cementation picking up below 250 mbsf (Prior et al., this volume). The first physical property evidence for the onset of significant cementation with depth is the relatively large increase in seismic velocity (Fig. 10A) between $\sim 280-350$ mbsf (the velocity data is too sparse in this interval to locate the boundary more accurately). The $\sim 400 \mathrm{mbsf}$ level represent the upper boundary of a major cementation zone in this section. The porosity also decreases downward relatively abruptly between $\sim 390$ and $430 \mathrm{mbsf}$ (Fig. 10B). This downward porosity decrease is further associated with an abrupt increase in thermal conductivity and appears to relate to the onset of zeolite plus clay cementation (Prior et al., this volume). The $\sim 400$ mbsf cementation front is associated with a substantial increase in the smectite content (Fig. 10D) of the section below this level; based on XRD analysis of the fine fraction (Kurnosov et al., this volume; Prior et al., this volume). The main zone of current fluid freshening is also most pronounced between $400-500$ mbsf just beneath this main cementation front and suggests that cementation may be continuing (Fig. 5).

Analysis by scanning electron microscopy (SEM) reveals what appear to be systematic timing relationships between the cement phases (Prior et al., this volume). The clays in the cementation zone 
Figure 5. Synthesis of the pore-fluid downhole profiles showing variations in chlorinity and total dissolved cation charge. Arrow represents approximate sea water composition.
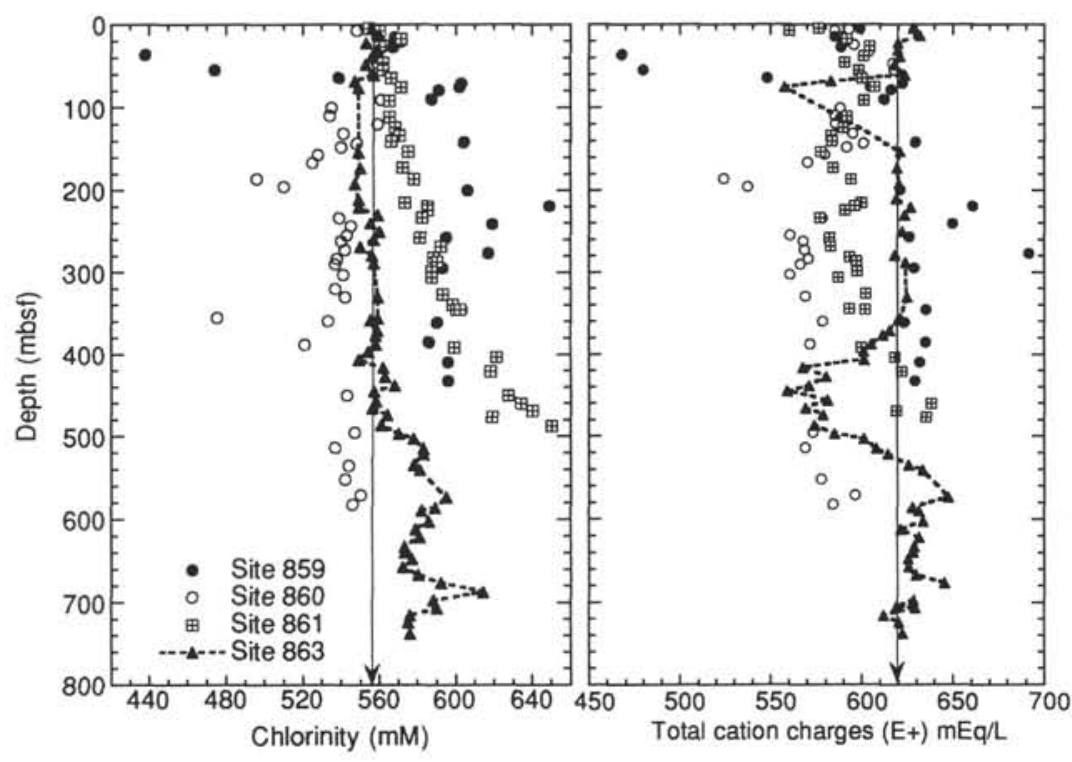

at Site 863 occur as authigenic pore filling phases; in some instances as thin filaments that fringe the grains. In other areas, they are sufficiently abundant to almost occlude the pore spaces (Prior et al., this volume). The clay cements are closely associated with $\mathrm{K}$ and $\mathrm{Ca}$ zeolites. While early clay cementation appears to predate the zeolites, clay and zeolite cementation have continued synchronously. The carbonate cements are observed at Site 863 predominantly as a late stage pore-and fracture-filling phases. Where they occur together, SEM observations indicate the carbonate post dates any clay mineral and zeolite cements (Prior et al., this volume). Early clay minerals and zeolites also appear to restrict the occurrence of the later carbonates where they are well developed. Carbonate veins (in some instances the carbonates are also associated with euhedral Fe-sulfide and quartz) begin to be observed below $397 \mathrm{mbsf}$ and occur in relatively discrete intervals ( $<1$ to $2 \mathrm{~m}$ thick) at $397 \mathrm{mbsf}, 416 \mathrm{mbsf}, 669 \mathrm{mbsf}$ and at 678 mbsf near the base of the hole (Prior et al., this volume). Generally, they are best developed in deformed regions; one particularly well developed example of complex "net-like veining" at 599 mbsf is in the hanging wall of a fault. Carbonate veins are also locally developed in the dilational jogs of irregular minor shear zones. The carbonate veins are clearly associated with discrete dilation along a limited number of fractures ( $\sim 0.1 \mathrm{~mm}$ thick).

\section{DISCUSSION}

Regional heat flow patterns to the south of the DFZ appear similar to other arcretionary prisms and suggest that regional permeability anisotropy (Arch and Maltman, 1990; Brown et al., 1994; Brown and Moore, 1993; Screaton et al., 1990) directs expulsion of consolidation-related fluids laterally towards the toe of the wedge (Fig. 4). The changes in the nature of the geochemical, and temperature profiles (Figs. 3 and 5-9) at the sites across the wedge also confirm the dominance of fluid flow within $5 \mathrm{~km}$ of the toe of the wedge (i.e., the highly non-linear profiles at Sites 859 and 863) and the dominance of conduction and diffusion processes in the interior regions (i.e., predominantly linear geochemical and temperature profiles at Site 861).

The narrowly confined, abrupt changes in downhole temperature at both Sites 859 and 863 also indicate a vigorous and transient hydraulic system (Fig. 3). There is the possibility that convection, driven by high heat input from the subducting ridge (Fig. 4), is partially responsible for the complex hydrogeologic patterns developed at the very toe of the prism; and at Site 859 in particular (Brown and Bangs, this volume). For example, the complex temperature profile at Site 859 could be a product of changes between vigorous, short-lived, focused lateral hot water flow along a narrow, highpermeability conduit between $235-245 \mathrm{mbsf}$ and intervening periods of large scale basement driven convection (Fig. 4); during which cool fluids are drawn through a hydrostatically pressured accretionary wedge (Brown and Bangs, this volume). Certainly, given the generally low permeability expected in the silty clays that predominate at this site, the required high permeability strongly suggests fracture controlled fluid flow at the $\sim 245 \mathrm{mbsf}$ level of the temperature spike.

The fluid chemistry of other accretionary systems that have been studied during ODP drilling, such as the Barbados, Nankai, and Cascadia wedges, are commonly proposed to be influenced by freshening resulting from the release of water during the dehydration and conversion of smectite to illite at relatively deep levels in the prism at temperature of between $80^{\circ}-150^{\circ} \mathrm{C}$ (Moore and Vrolijk, 1992). These fluids are associated with negative chloride anomalies and commonly a thermogenic methane component (Gieskes et al., 1990a, b; Vrolijk et al., 1990, 1991). In strong contrast, the elevated salinity and chloride values (Fig. 5) indicate that the subduction of the spreading ridge at the CTJ results in net hydration of the oceanic basement, the overriding continental basement, and a significant portion of the accretionary wedge. For example, the chloride values at 859 are elevated $\sim 10 \%$ above average sea water chloride values, while at Site 861 they are elevated by $\sim 20 \%$. Note, there is no evidence for any evaporates in the CTJ region that might produce these effects (unlike Peru; Kastner et al., 1991). Furthermore, the data at Site 863 also suggest that the regions immediately overlying the subducting spreading center will experience an infusion of primordial ${ }^{4} \mathrm{He}$ accompanied by greatly increased diagenesis and cementation.

The region around Site 860 , which lies approximately above the center of the wedge, is the only site where low salinities and chloride values are prominent. In this central region of the wedge we are, perhaps, seeing "remnant" low salinity fluids that have origins in the period that predates the generation of fluids with elevated chloride and salinity values during the current ridge subduction event.

Taken together with complex temperature and geochemical profiles, structural and diagenetic observations are consistent with a hydrogeologic regime that both evolves with time and that is dominated by episodic processes. In particular, studies of veins, deformation bands, and Fe sulfide distribution suggest that periods of enhanced fluid expulsion through the wedge above the subducted spreading center may be associated with local dilation and fluid flow. The nature of the coupling between diagenesis, lithology and changing mechanisms of fluid flow is most clearly demonstrable at Site 863. The hydraulic properties of the sediments largely define the patterns 

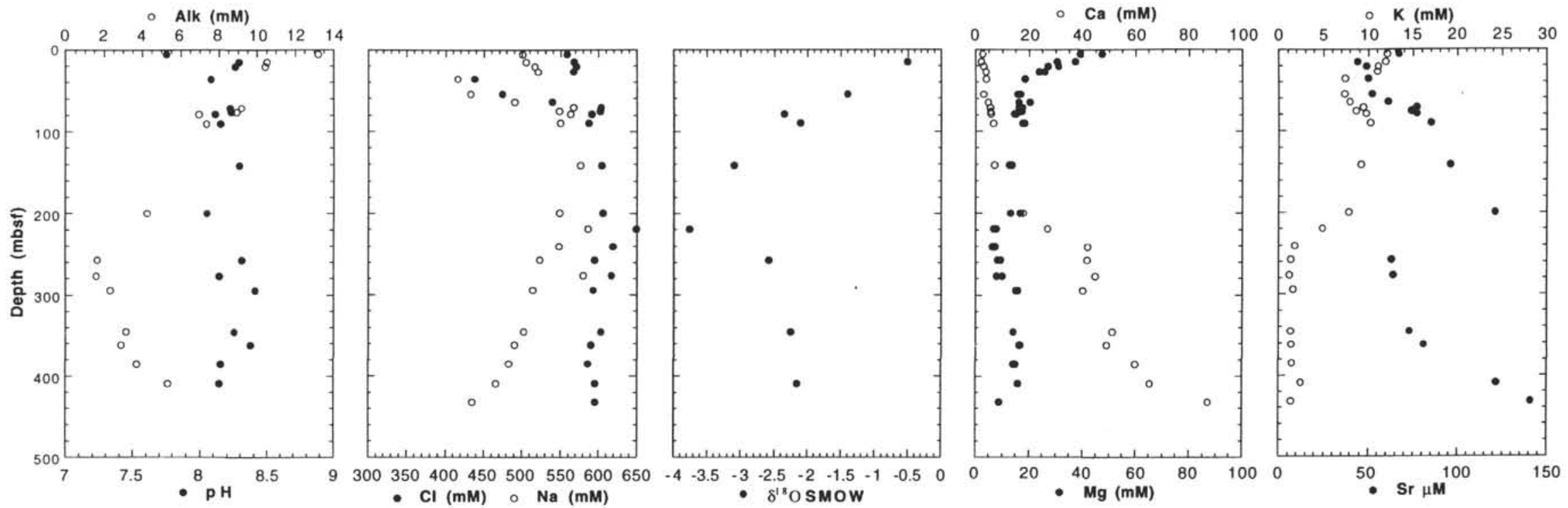

Figure 6. Summary of some of the main pore water characteristics from Site 859 (Behrmann, Lewis, Musgrave, et al., 1992). ( $\delta^{18} \mathrm{O}$ data is taken from Zheng et al., this volume).

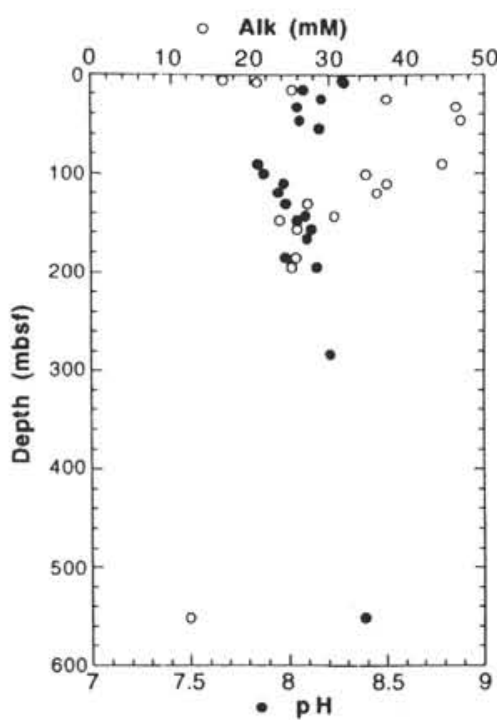

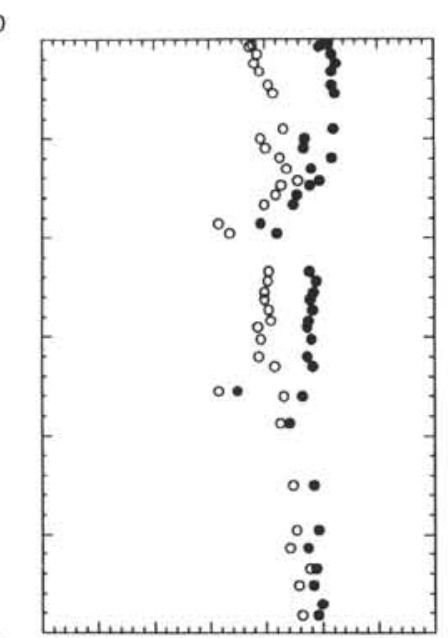

3003504004505005506006

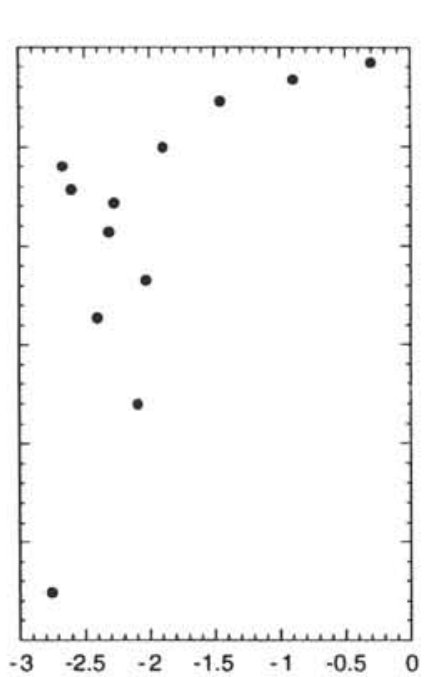

- $\delta^{18} \mathrm{O}$ SMOW
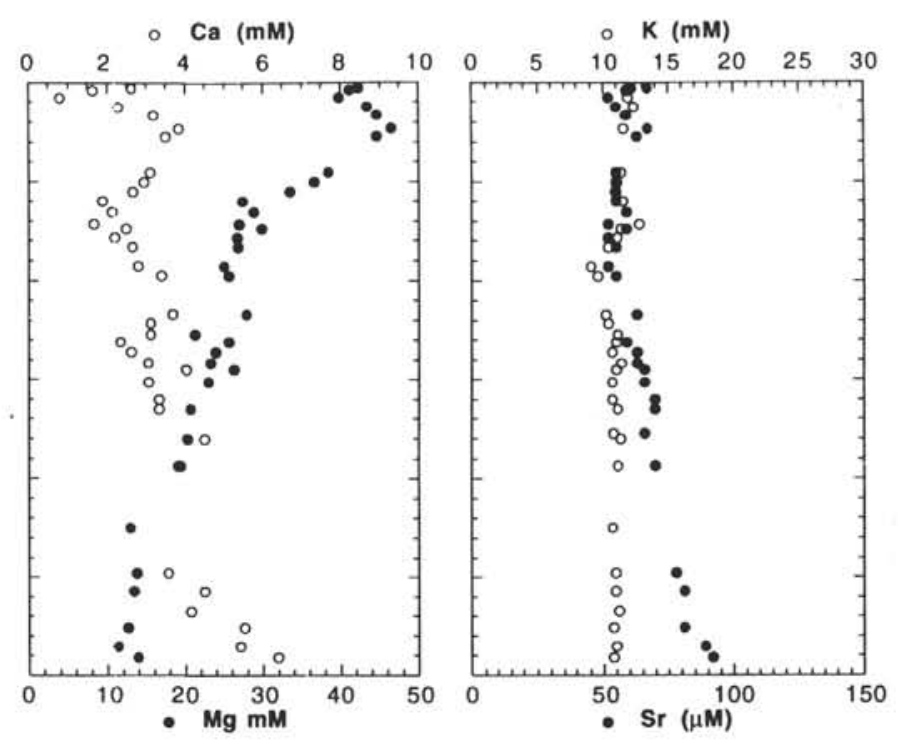

Figure 7. Summary of some of the main pore water characteristics from Site 860 (Behrmann, Lewis, Musgrave, et al., 1992). ( $\delta^{18} \mathrm{O}$ data is taken from Zheng et al., this volume). 

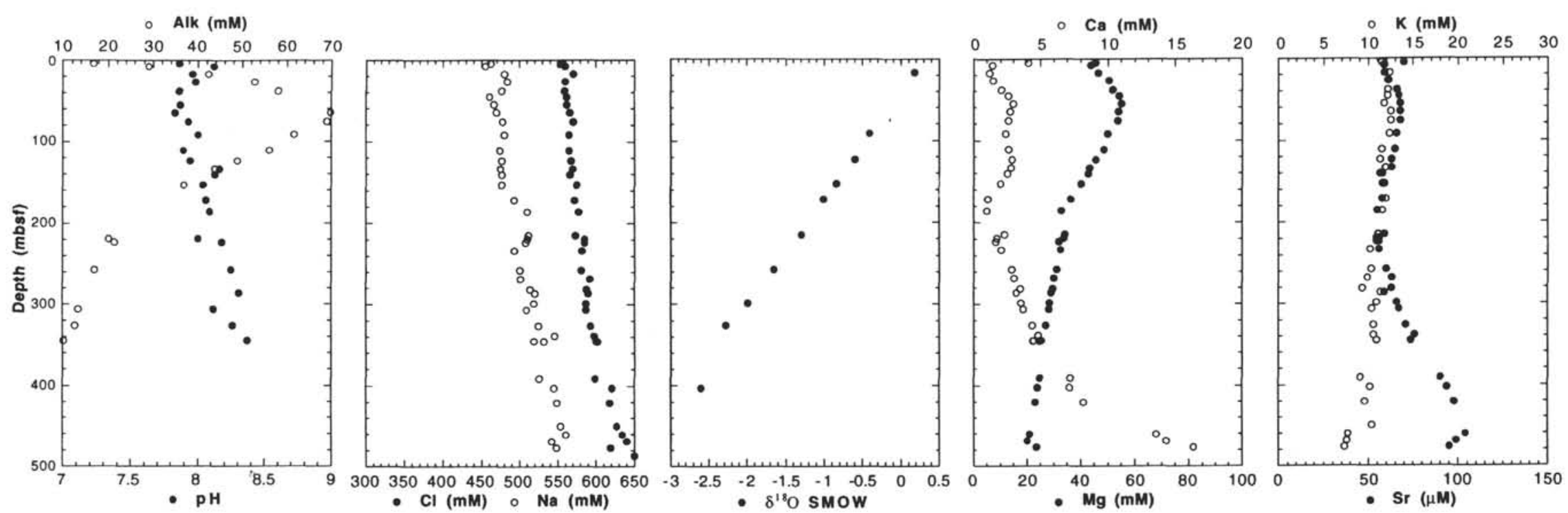

Figure 8. Summary of some of the main pore water characteristics from Site 861 (Behrmann, Lewis, Musgrave, et al., 1992). ( $\delta^{18} \mathrm{O}$ data is taken from Zheng et al., this volume).
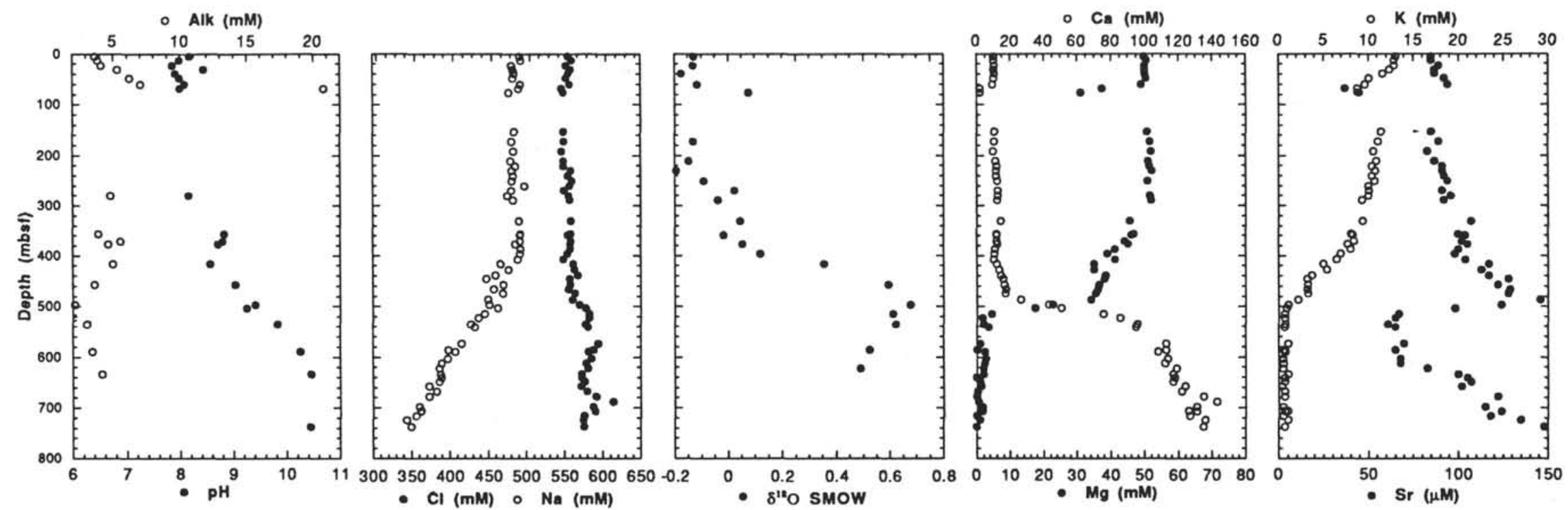

Figure 9. Summary of some of the main pore water characteristics from Site 863 (Behrmann, Lewis, Musgrave, et al., 1992). ( $\delta^{18} \mathrm{O}$ data is taken from Zheng et al., this volume). 


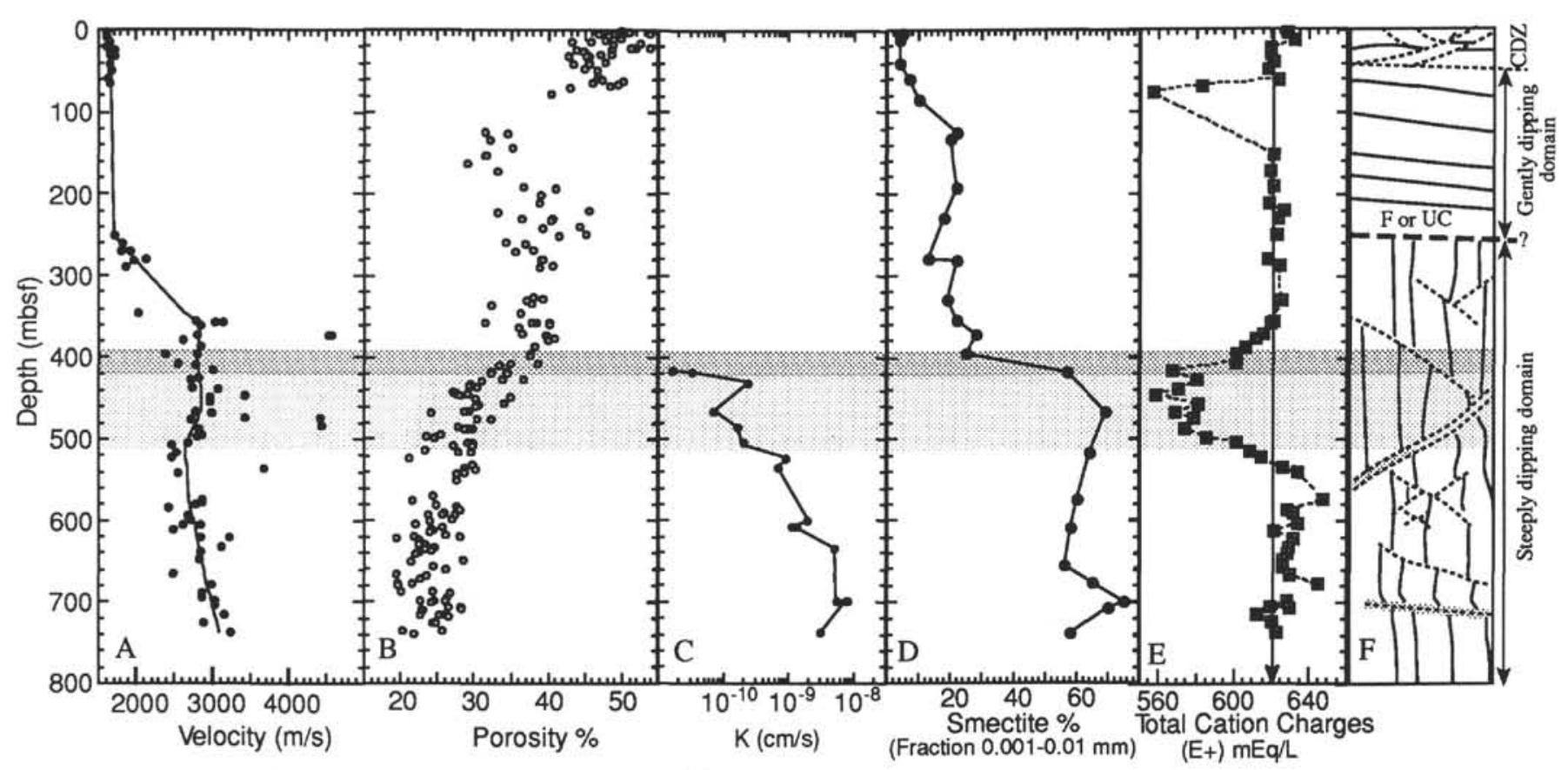

Figure 10. Summary of hydrogeologic, physical property, and mineralogic data from Site 863 (Brown, this volume; Kurnosov et al., this volume; Prior et al., this volume).

of fluid flow. There is strong evidence for both intergranular and fracture controlled flow mechanism at Site 863. The major cementation zone that develops below 400 mbsf (Fig. 10) and extends downwards to the base of the hole is largely generated by clay-zeolite (plus calcite) deposition from fluids moving by intergranular flow through the more permeable coarser lithologies such as the graded bases of the subvertical turbidites (see "Site 863" chapter in Behrmann, Lewis, Musgrave, et al., 1992). The top of this main cementation zone is abrupt and associated with reduced intergranular hydraulic conductivities (Brown, this volume). The restricted nature of calcite deposition in regions of substantial clay and zeolite cementation suggests an evolving complex pattern of permeability where initial fluid pathways become increasingly blocked deflecting flow to surrounding regions (Prior et al., this volume). Veins containing the later calcite cements suggests that the fluid migration mechanisms changed during this period from intergranular flow to fracture controlled flow that may be associated with episodic hydrofracturing. Given its very low hydraulic conductivities, it is quite possible that the cementation front has generated a seal with increasing degrees of overpressure development in a "pressure compartment" beneath (Hunt, 1990).

\section{CONCLUSIONS}

In conclusion, the subduction of the oceanic spreading center beneath the accretionary wedge at the CTJ represents a complex hydrogeologic and tectonic environment. The subduction event is associated with the development of the following principal features in the overriding plate:

1. A generally elevated regional heat flow that increases nonlinearly toward the toe of the wedge.

2. A hydrogeologic system that is dominated by conduction/ diffusion processes in the interior eastern wedge/continental backstop region; and vigorous transient hydrogeologic activity within 5 $\mathrm{km}$ of the toe of the wedge. The hydrogeologic activity is associated with highly irregular temperature and geochemical pore water profiles related to spatially focused fluid flow events.
3. The general elevation of salinities and chloride values to levels above average seawater concentrations in response to enhanced hydration in much of the wedge and continental backstop region.

4. The input of primordial ${ }^{4} \mathrm{He}$ to the wedge immediately above the subducted spreading center.

5. Enhanced diagenetic activity, cementation, and veining that is particularly evident in the wedge above the subducted spreading center.

\section{ACKNOWLEDGMENTS}

The authors would like to thank the crew and technical support staff aboard the JOIDES Resolution for their considerable efforts to make ODP Leg 141 a successful and enjoyable drilling leg. We also thank Mike Tryon for help with drafting of some of the figures and Roisin Lawrence for commenting on early drafts of the paper.

\section{REFERENCES}

Arch, J., and Maltman, A., 1990. Anisotropic permeability and tortuosity in deformed wet sediments. J. Geophys. Res., 95:9035-9046.

Behrmann, J.H., Lewis, S.D., Musgrave, R.J., et al., 1992. Proc. ODP, Init, Repts., 141: College Station, TX (Ocean Drilling Program).

Brown, K.M., 1990. The nature and hydrogeologic significance of mud diapirs and diatremes for accretionary systems. J. Geophys. Res., 95:8969-8982.

Brown, K.M., Bekins, B., Clennell, B., Dewhurst, D., and Westbrook, G., 1994. Heterogeneous hydrofracture development and accretionary fault dynamics. Geology, 22:259-262.

Brown, K.M., and Moore, J.C., 1993. Comment on "Anisotropic permeability and tortuosity in deformed wet sediments" by J. Arch and A. Maltman. J. Geophys. Res., 98:17859-17864.

Cande, S.C., Leslie, R.B., Parra, J.C., and Hobart, M., 1987. Interaction between the Chile Ridge and Chile Trench: geophysical and geothermal evidence. J. Geophys. Res., 92:495-520.

\footnotetext{
- Abbreviations for names of organizations and publications in ODP reference lists follow the style given in Chemical Abstracts Service Source Index (published by American
} Chemical Society). 
Cloos, M., 1993. Lithospheric buoyancy and collisional orogenesis: subduction of oceanic plateaus, continental margins, island arcs, spreading ridges, and seamounts. Geol. Soc. Am. Bull., 105:715-737.

DeLong, S.E., Schwarz, W.M., and Anderson, R.N., 1979. Thermal effects of ridge subduction. Earth Planet. Sci. Lett., 44:239-246.

Gieskes, J.M., Blanc, G., Vrolijk, P., Elderfield, H., and Barnes, R., 1990a. Interstitial water chemistry-major constituents. In Moore, J.C., Mascle, A., et al., Proc. ODP, Sci. Results, 110: College Station, TX (Ocean Drilling Program), 155-178.

Gieskes, J.M., Vrolijk, P., and Blanc, G., 1990b. Hydrogeochemistry of the northern Barbados accretionary complex transect: Ocean Drilling Program Leg 110. J. Geophys. Res., 95:8809-8818.

Hunt, J.M., 1990. Generation and migration of petroleum from abnormally pressured fluid compartments. AAPG Bull., 74:1-12.

Kastner, M., Elderfield, H., and Martin, J.B., 1991. Fluids in convergent margins; what do we know about their composition, origin, role in diagenesis and importance for oceanic chemical fluxes? Philos. Trans. R. Soc. London A, 335:243-259.

Kastner, M., Elderfield, H., Martin, J.B., Suess, E., Kvenvolden, K.A., and Garrison, R.E., 1990. Diagenesis and interstitial-water chemistry at the Peruvian continental margin-major constituents and strontium isotopes. In Suess, E., von Huene, R., et al., Proc. ODP, Sci. Results, 112: College Station, TX (Ocean Drilling Program), 413-440.

Knipe, R.J., Agar, S.M., and Prior, D.J., 1991. The microstructural evolution of fluid flow paths in semi-lithified sediments from subduction complexes. Philos. Trans. R. Soc. London A, 335:261-273.

Moore, J.C., and Vrolijk, P., 1992. Fluids in accretionary prisms. Rev. Geophys., 30:113-135.
Screaton, E.J., Wuthrich, D.R., and Dreiss, S.J., 1990. Permeabilities, fluid pressures, and flow rates in the Barbados Ridge Complex. J. Geophys. Res., 95:8997-9007.

Underwood, M.B. (Ed.), 1993. Thermal Evolution of the Tertiary Shimanto Belt, Southwest Japan: An Example of Ridge-Trench Interaction. Spec. Pap.-Geol. Soc. Am., 273.

Underwood, M.B., Shelton, K.L., Laughland, M.M., Clendenen, W., and Heizler, M., 1989. Thermal maturity and fluid-rock interactions, Franciscan accretionary complex, Big Sur, California. Geol. Soc. Am. Abstr. Progr., 21:338.

Underwood, M.B., Shelton, K.L., and Solomon, R.M., 1990. Miocene hydrothermal overprint and tectonic evolution of the King Range, northern coast of California. Eos, 71:1223.

Vrolijk, P., Chambers, S.R., Gieskes, J.M., and O'Neil, J.R., 1990. Stable isotope ratios of interstitial fluids from the Northern Barbados Accretionary Prism, ODP Leg 110. In Moore, J.C., Mascle, A., et al., Proc. ODP, Sci. Results, 110: College Station, TX (Ocean Drilling Program), 189-205.

Vrolijk, P., Fisher, A., and Gieskes, J., 1991. Geochemical and geothermal evidence for fluid migration in the Barbados accretionary prism (ODP Leg 110). Geophys. Res. Lett., 18:947-950.

Date of initial receipt: 29 June 1994

Date of acceptance: 24 February 1995

Ms 141SR-034 